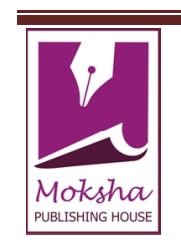

INTERNATIONAL RESEARCH JOURNAL OF PHARMACY

www.irjponline.com

ISSN $2230-8407$

Research Article

\title{
DEVELOPMENT OF A SIMPLE UV-SPECTROPHOTOMETRIC ASSAY METHOD FOR SATRANIDAZOLE AND STUDY OF ITS DEGRADATION PROFILE
}

\author{
Vishwanath Agrahari*1 ${ }^{1}$, Meenakshi Bajpai ${ }^{2}$, Sanju Nanda ${ }^{3}$ \\ ${ }^{1}$ College of Pharmaceutical Sciences, RKGIT, Ghaziabad-201003, UP, India \\ ${ }^{2}$ Faculty of Pharmacy, Uttarakhand Technical University, Dehradun, India \\ ${ }^{3}$ Department of Pharmaceutical Sciences, M.D. University, Rohtak-124001, Haryana, India \\ E-mail:v09world@gmail.com
}

Article Received on: 18/02/13 Revised on: 01/03/13 Approved for publication: 17/04/13

DOI: $10.7897 / 2230-8407.04442$

IRJP is an official publication of Moksha Publishing House. Website: www.mokshaph.com

(C) All rights reserved.

\section{ABSTRACT}

A simple, selective, rapid, precise, economical, reproducible and stability-indicating UV spectrophotometric method has been developed and validated for determination of Satranidazole in pure form and pharmaceutical dosage form. From solvent effect studies and the spectral behaviour of Satranidazole, methanol was selected as solvent. The UV spectrum was scanned between 200 to $400 \mathrm{~nm}$ and 318 nm was selected as maximum wavelength for absorption. Beer's law was obeyed in the concentration range of 2-30 $\mu \mathrm{g} / \mathrm{mL}$. The regression coefficient was 0.999 . The method was validated for accuracy, precision, specificity and robustness, in accordance with ICH guidelines. Recovery studies gave satisfactory results indicating that none of common additives and excipients or the degraded impurities interfere in the assay method. Statistical analysis proved the method was precise, reproducible, selective, specific, and accurate for analysis of Satranidazole. Stability testing study includes the effect of oxidation, photolysis and susceptibility to hydrolysis across a wide range of $\mathrm{pH}$ values. The wide linearity range, accuracy and easy preparation of diluent imply the method is suitable for routine quantification of Satranidazole in the quality control of bulk forms and pharmaceutical dosage forms with high precision and accuracy.

Key Words: Satranidazole, UV Spectrophotometry, Stability indicating, Validation, ICH.

\section{INTRODUCTION}

Satranidazole, a novel nitroimidazole possessing a C-N linkage at $\mathrm{C}_{2}$ of the imidazole ring has been examined (during reduction), for its ability to damage DNA. The drug produces extensive DNA damage characterized by helix destabilization and strand breakage. Its comparison with other 2- and 5-nitroimidazoles indicates it may be more active towards anaerobes than many 5-nitroimidazoles. It is due to its relatively high redox potential which may make it more resistant to inactivation by oxygen ${ }^{1}$. It is a highly potent, well-tolerated, and clinically useful agent against common protozoa. It is rapidly absorbed and exhibits higher plasma and liver concentration than metronidazole. Satranidazole (SAT) is not included in any official pharmacopoeias such as IP, USP and BP. Chemically, it is 3(1-methyl-5-nitroimidazol-2-yl)-1-(methylsulfonyl)

imidazolidin-2-one. Its molecular formula is $\mathrm{C}_{8} \mathrm{H}_{11} \mathrm{~N}_{5} \mathrm{O}_{5} \mathrm{~S}$ and molecular weight is 289.26 . The structure of active moiety is mentioned in Figure.1. Literature survey revealed an electron-capture gas chromatographic assays in blood ${ }^{2}$, spectrophotometric methods ${ }^{3,4,5,6}$, HPTLC methods ${ }^{7,8}$ and HPLC methods ${ }^{9,10,11,12}$ in pharmaceutical dosage form for estimation of Satranidazole individually as well as in combination with Ofloxacin. Spectrophotometric method is generally preferred especially by small-scale industries as the cost of the equipment is less and the maintenance problems are minimal. The method of analysis is based on measuring the absorption of a monochromatic light by colorless compounds in the ultraviolet path of spectrum i.e. 200 to $400 \mathrm{~nm}^{13}$. So an attempt has been made to develop a new stability indicating UV spectrophotometric method for its estimation in pharmaceutical dosage form with good accuracy, precision and simplicity.

Stability indicating assay methods (SIAMs) is defined as validated quantitative analytical methods that can detect the changes with time in the chemical, physical or microbiological properties of the drug substance and drug product, and that are specific so that the contents of active ingredient, degradation products, and other components of interest can be accurately measured without interference. The United States Pharmacopoeia (USP) has a requirement listed under 'Stability Studies in Manufacturing', which says that samples of the products should be assayed for potency by the use of a stability-indicating assay. The requirement in such a clear and detailed manner is, however, absent in other pharmacopoeias. The method was validated according to the ICH $_{\text {guidelines }}{ }^{14,15,16}$.

\section{MATERIALS AND METHODS}

\section{Chemicals}

All the chemicals and reagents used were of analytical grade. Distilled water was obtained using millipore water purification system. Working standard of satranidazole with potency of $99.67 \%$ was obtained from Alkem Laboratories Limited, Baddi. Commercial tablets containing Satranidazole (Satrogyl-300mg) were procured from the local chemist shop. All volumetric glass-ware was pre-calibrated by the manufacturer (Borosil) and was of grade A. Aqueous solutions of hydrochloric acid, sodium hydroxide, hydrogen peroxide were prepared in the usual way.

\section{Instrumentation}

A PC based Shimadzu 1700 UV-Visible double beam spectrophotometer with spectral band-width of $1.8 \mathrm{~nm}$, wavelength accuracy of $2 \mathrm{~nm}$ and two matched quartz cuvettes of $10 \mathrm{~mm}$ optical path length was used along with UV Probe software. Another instrument used was Systronics UV-VIS spectrophotometer Type 118 single beam with spectral band width of $3 \mathrm{~nm}$.

\section{Method Development}

Different solvents were investigated to develop a suitable UV spectrophotometric method for the analysis of satranidazole in formulation. The criteria employed were the solubility of 
the drug, easiness of the sample preparation, maximum absorbance and specificity of the method. Methanol was selected as the diluent because of the total solubilization of the drug in this solvent. The cut off wavelength of methanol is $205 \mathrm{~nm}$ hence it will not interfere in the absorption of wavelength in the UV range.

\section{Standard solution preparation}

Standard stock solution was prepared by dissolving $10 \mathrm{mg}$ of satranidazole API in $8.0 \mathrm{ml}$ of methanol in $10 \mathrm{ml}$ volumetric flask. It was sonicated for 15 minutes with occasional swirling, cooled and made up the volume up to $10.0 \mathrm{ml}$ with the same to obtain concentration of $1000 \mu \mathrm{g} / \mathrm{ml}$ of the drug. It was filtered through a $0.45 \mu$ membrane filter. The stock solution was protected from light using aluminium foil and stored for 1 week at $4^{0} \mathrm{C}$ and was found to be stable during this period.

\section{Construction of calibration curve}

Standard stock solution were accurately transferred into a series of $10 \mathrm{ml}$ calibrated volumetric flask and made up to the mark with methanol to obtain concentrations in the range of $2-30 \mathrm{mcg} / \mathrm{ml}$. The absorbance of resulting solutions was measured at $318 \mathrm{~nm}$ against methanol blank. Calibration curve was prepared by plotting the absorbance versus concentration of the drug.

\section{Assay Procedure}

20 Tablets of the product under study were weighed, crushed and mixed in a mortar and pestle. A portion of powder equivalent to the weight of $50 \mathrm{mg}$ was accurately weighed and transferred to a dry $50 \mathrm{ml} \mathrm{A-grade} \mathrm{volumetric} \mathrm{flask} \mathrm{and}$ $40 \mathrm{ml}$ methanol was added. The volumetric flask was sonicated for $15 \mathrm{~min}$ to effect complete dissolution of satranidazole. It was cooled, made up to the mark by diluent and filtered through a $0.45 \mu \mathrm{m}$ nylon filter. The absorbance of the resulting solution at the $\lambda_{\max }$ was noted down and the content was determined.

\section{Conduct of stress studies}

The stress studies were carried out under the conditions of dry heat, UV-degradation, hydrolysis and oxidation. For dry heat stress testing, solid drug was kept in Petri dish in an oven at $105^{\circ} \mathrm{C}$ for $4 \mathrm{~h}$ and after cooling to room temperature, $10 \mathrm{mg}$ of SAT was weighed and transferred to a $10 \mathrm{~mL}$ calibrated flask, dissolved in methanol and diluted up to the mark with the same solvent. The absorption spectrum was recorded from 200-400 $\mathrm{nm}$. The UV degradation study was carried out by exposing the solution of SAT $(20 \mu \mathrm{g} / \mathrm{mL})$ to UV radiation in a UV chamber at shorter wavelength for $4 \mathrm{hr}$ and the absorption spectrum was recorded. For acid, alkali and oxidative degradation studies, $2 \mathrm{~mL}$ of $100 \mu \mathrm{g} / \mathrm{mL}$ SAT was taken separately in three $10 \mathrm{~mL}$ calibrated flasks and mixed with $5 \mathrm{~mL}$ of $1 \mathrm{M} \mathrm{HCl}$ (acid hydrolysis) or $1 \mathrm{M} \mathrm{NaOH}$ (alkaline hydrolysis) or $3 \% \mathrm{H}_{2} \mathrm{O}_{2}$ (oxidative degradation) and kept on hot water bath set at $80{ }^{\circ} \mathrm{C}$ for $2 \mathrm{~h}$. Then, the solution was cooled to room temperature and diluted to the mark with methanol and the absorption spectra of the resulting solutions $(20 \mu \mathrm{g} / \mathrm{mL})$ were recorded. The absorbance values obtained in stress studies were compared with the data obtained in calibration curve i.e. in the absence of forced degradation.

Table 1: Evaluation of Intra-day and Inter-day precision

\begin{tabular}{|c|c|c|c|c|}
\hline \multirow{2}{*}{ Conc. $(\boldsymbol{\mu g} / \mathbf{m l}))$} & \multicolumn{2}{|c|}{ Repeatability (intra-day precision) } & \multicolumn{2}{c|}{ Intermediate precision(inter-day) } \\
\cline { 2 - 5 } & Mean Abs (n=3) & RSD (\%) & Mean Abs (n=3) & 0.79 \\
\hline 12 & 0.485 & 0.62 & 0.481 & 0.73 \\
\hline 16 & 0.616 & 0.73 & 0.614 & 0.49 \\
\hline 20 & 0.769 & 0.54 & 0.771 & RSD \\
\hline
\end{tabular}

Table 2: Accuracy data as recovery

\begin{tabular}{|c|c|c|c|c|c|}
\hline $\begin{array}{l}\text { Amount (\%) of drug } \\
\text { added to analyte }\end{array}$ & $\begin{array}{c}\text { Theoretical content } \\
(\mu \mathrm{g} / \mathrm{ml})\end{array}$ & $\begin{array}{c}\text { conc. Found }(\mu \mathrm{g} / \mathrm{ml}) \\
\pm \text { SD }\end{array}$ & $\begin{array}{c}\text { Recovery } \\
(\%)\end{array}$ & $\begin{array}{c}\text { RSD (\%) } \\
n=3\end{array}$ & SEM \\
\hline 80 & 18 & $18.07 \pm 0.11$ & 100.39 & 0.6 & 0.06 \\
\hline 120 & 22 & $21.81 \pm 0.10$ & 99.12 & 0.46 & 0.06 \\
\hline
\end{tabular}

Table 3: Ruggedness data

\begin{tabular}{|c|c|c|c|c|}
\hline \multirow{2}{*}{ Conc. $(\boldsymbol{\mu g} / \mathbf{m l}))$} & \multicolumn{4}{|c|}{ RSD (\%) $\mathbf{n = 3}$} \\
\cline { 2 - 5 } & By Analyst 1 & By Analyst 2 & Instrument 1 & Instrument 2 \\
\hline 12 & 0.62 & 0.71 & 0.75 & 0.81 \\
\hline 16 & 0.73 & 0.69 & 0.64 & 0.94 \\
\hline 20 & 0.54 & 0.62 & 0.72 & 0.87 \\
\hline
\end{tabular}

Table 4: Robustness data

\begin{tabular}{|c|c|c|c|}
\hline $\mathbf{2 0} \boldsymbol{\mu g} / \mathbf{m L}$ of sample at different wavelengths & conc. Found $(\boldsymbol{\mu g} / \mathbf{m l})$ & Recovery $(\%)$ & RSD $(\%)$ \\
\hline \multirow{3}{*}{$317 \mathrm{~nm}$} & 19.92 & 99.61 & 0.73 \\
\cline { 2 - 4 } & 20.11 & 100.53 & \\
\cline { 2 - 4 } & 20.21 & 101.05 & \\
\hline \multirow{3}{*}{$318 \mathrm{~nm}$} & 20.10 & 100.52 & 0.27 \\
\cline { 2 - 4 } & 20.08 & 100.39 & \\
\cline { 2 - 4 } & 20.18 & 99.09 & 0.60 \\
\hline \multirow{2}{*}{$319 \mathrm{~nm}$} & 19.82 & 99.87 & \\
\cline { 2 - 4 } & 19.97 & 100.26 & \\
\hline
\end{tabular}


Vishwanath Agrahari et al. Int. Res. J. Pharm. 2013, 4 (4)

Table 5: Result of forced degradation study of Stranidazole

\begin{tabular}{|c|c|c|c|}
\hline Stress conditions & $\begin{array}{c}\text { Concentration } \\
\text { taken }(\boldsymbol{\mu g} / \mathbf{m l})\end{array}$ & \% Recovery & Comments \\
\hline Neutral hydrolysis & 20 & 99.61 & Not degraded \\
\hline Acidic hydrolysis & 20 & 100.65 & Not degraded \\
\hline Alkali hydrolysis & 20 & 5.47 & Wavelength changed and completely degraded \\
\hline Oxidation & 20 & 99.35 & Not degraded \\
\hline Heat at $100^{\circ} \mathrm{C}$ & 20 & 101.82 & Not degraded \\
\hline UV radiation & 20 & 98.44 & Not degraded \\
\hline
\end{tabular}

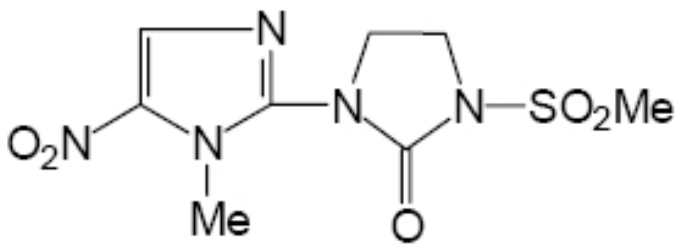

Figure 1. 3-(1-Methyl-5-nitroimidazol-2-yl)-1-(methylsulfonyl)imidazolidin-2-one

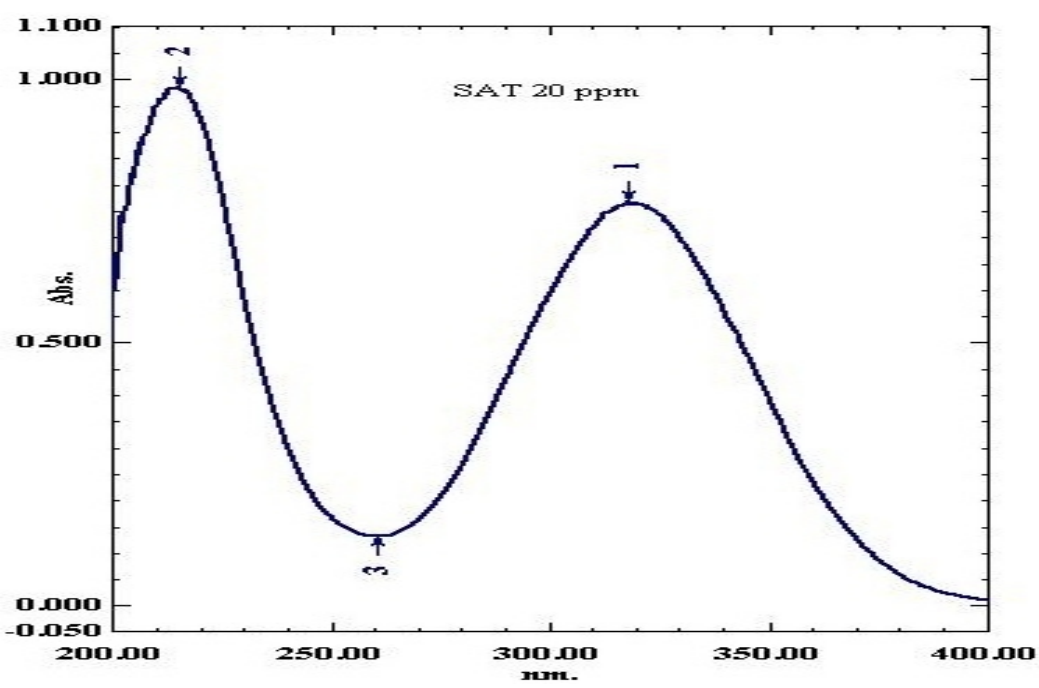

Figure 2. Absorption spectrum of Satranidazole (SAT) in methanol $(20 \mu \mathrm{g} / \mathrm{ml})$

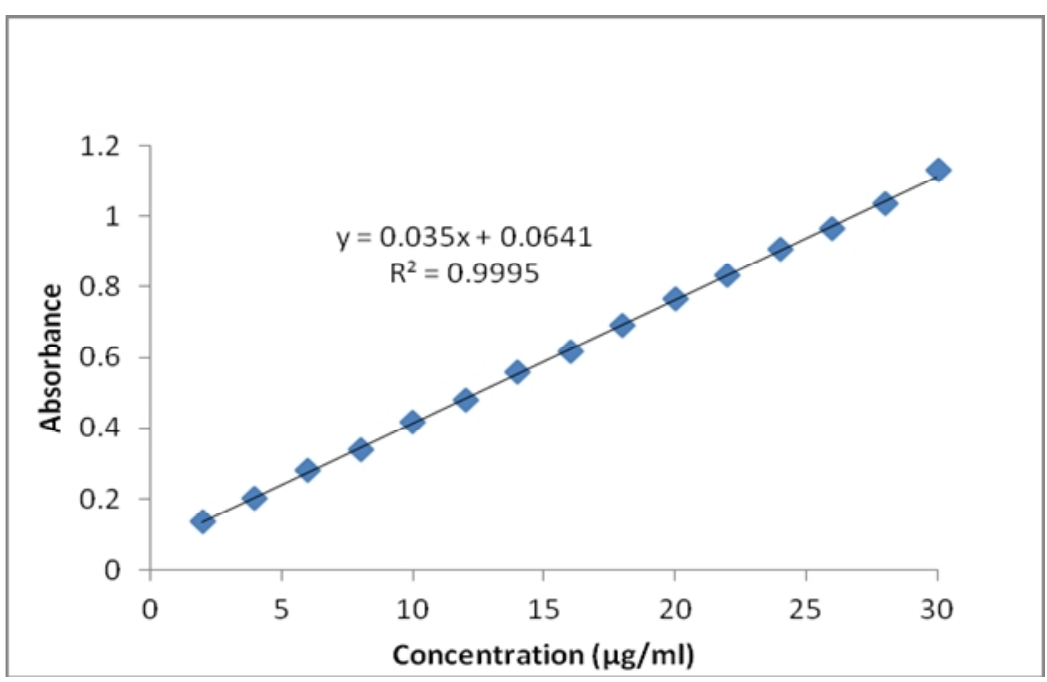

Figure 3. Linearity curve of Satranidazole in methanol 


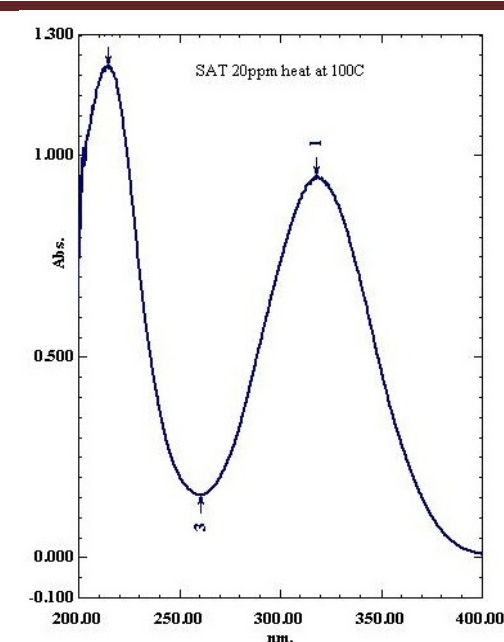

(a)

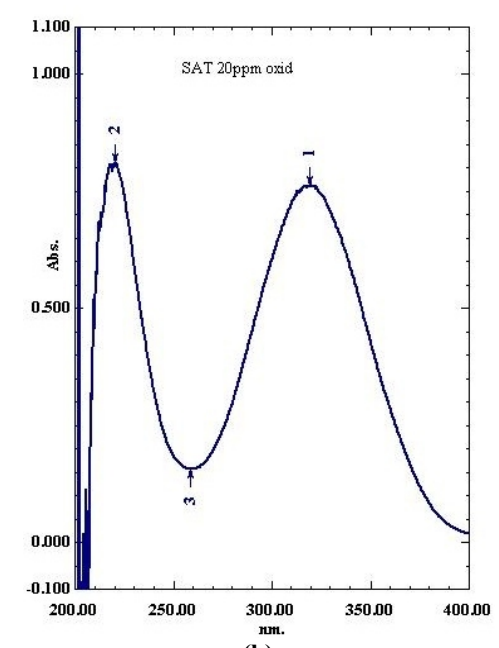

(b)

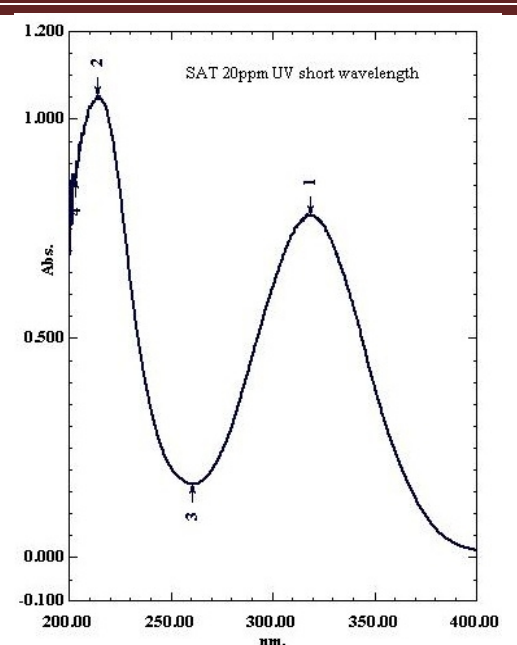

(c)

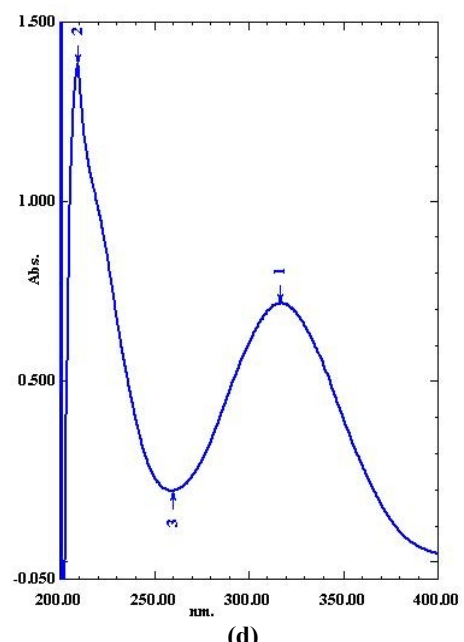

(d)

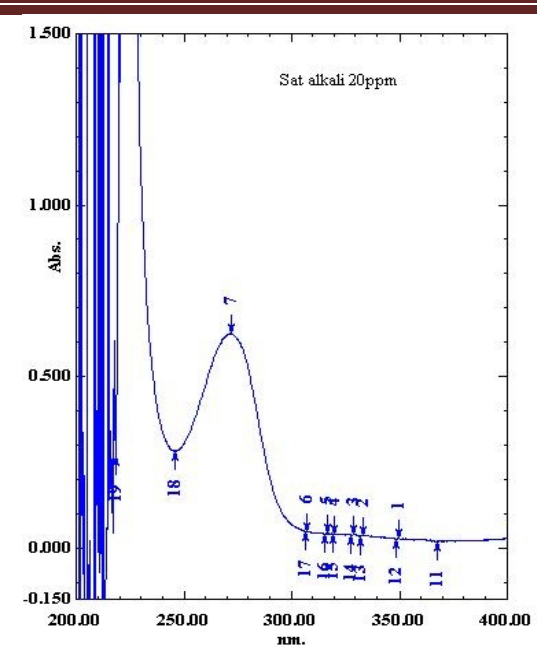

(e)

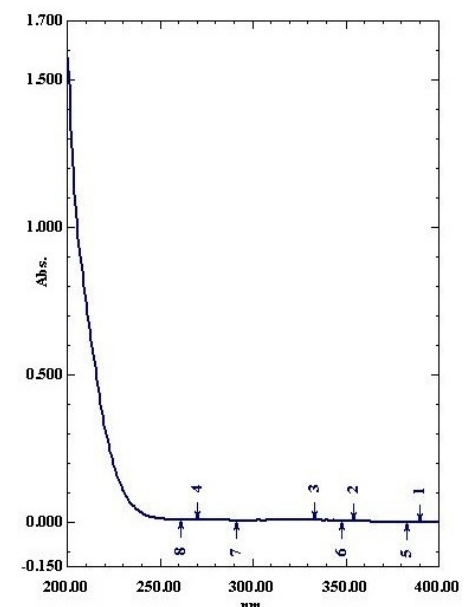

(f)

Figure 4. Degradation study of SAT solution (a) treated with dry heat at $100^{\circ} \mathrm{C}(\mathrm{b})$ oxidative degradation (c) UV radiation for shorter wavelength (d) treated with $\mathrm{HCl}(\mathrm{e})$ with $\mathrm{NaOH}(f)$ with $\mathrm{NaOH}$ after 24 hrs.

\section{RESULTS AND DISCUSSION}

\section{Spectral characteristics}

The absorption spectrum of $20 \mu \mathrm{g} / \mathrm{mL}$ SAT solution in methanol was recorded between $200-400 \mathrm{~nm}$ and showed an absorption maximum $(\lambda \max )$ at $318 \mathrm{~nm}$. At this wavelength methanol had insignificant absorbance. Therefore, $318 \mathrm{~nm}$ was used as analytical wavelength. Figure. 2 represents the absorption spectra of SAT in methanol along with methanol blank.

\section{Method Validation \\ Linearity}

A series of standard curves were prepared over a concentration range of $2-30 \mu \mathrm{g} / \mathrm{ml}$ by diluting the standard stock solution of SAT $(1 \mathrm{mg} / \mathrm{ml})$ in diluents. Triplicate determinations on each of the concentration levels were analyzed. The data from drug absorbance versus drug concentration plots were treated by linear least square regression analysis and $\mathrm{r}^{2}$ was found 0.999 (Figure.3).

\section{Precision}

Precision was determined as both repeatability and intermediate precision, in accordance with ICH recommendations. Repeatability of sample absorbance was determined as intra-day variation. Intermediate precision was determined by absorbance measurement of inter-day variation. For both intra-day and inter-day variation were performed at three different concentration levels in triplicate (Table 1).

\section{Accuracy, as Recovery}

Recovery studies by the standard addition method were performed with a view to justify the accuracy of the proposed method. Previously analyzed samples SAT $(10 \mu \mathrm{g} / \mathrm{ml})$ were spiked with known amount of standard so as to get three different levels $(80 \%, 100 \%$ and $120 \%)$ and the mixtures were analyzed by the proposed method. The experiment was performed in triplicate. Recovery (\%), RSD (\%) were calculated for each concentration. The results of accuracy is given in Table 2.

\section{Ruggedness}

The ruggedness of the method was demonstrated by analysis of the samples as for precision study by a second analyst and other instrument. The RSD of the two sets of data indicates the ruggedness of the method. The difference was found to be non-significant (Table 3 ). 


\section{Robustness}

The robustness of the method was determined to assess the effect of small but deliberate changes of the spectrophotometric conditions on the determination of SAT. The variation was difference in wavelength by $\pm 1 \mathrm{~nm}$. The concentration of the solution analyzed was $20 \mu \mathrm{g} / \mathrm{mL}$ (Table $4)$.

\section{Selectivity}

The proposed method was tested for selectivity by placebo containing mixture of commonly used tablet excipients, for example starch, microcrystalline cellulose, lactose, talc, magnesium stearate, colloidal silicon dioxide, sodium starch glycollate etc. It was found that there was no interference from the inactive ingredients as indicated by the blank absorbance. This result shows the selectivity of the method.

\section{Forced degradation of SAT}

Forced degradation studies provide an indication of the stability-indicating property of the drug. The study was carried out after subjecting SAT to dry heat treatment, UVdegradation, acid and alkali hydrolysis; and oxidation. The UV spectra of stress SAT samples which were subjected to dry heat treatment, oxidation and UV-degradation (Figure. $4 \mathrm{a}, 4 \mathrm{~b}$ and $4 \mathrm{c}$ ) were similar to that of the standard SAT sample (Figure.2) and it showed that SAT did not undergo degradation under these conditions. SAT subjected to acid and alkali hydrolysis showed degradation, since the absorbance values obtained under these stressed conditions (Figure. 4d, 4e) were smaller than the original value of standard SAT sample (Figure.1). The degradation of SAT is much lesser under acidic environment in comparison to basic condition. The complete degradation observed under alkaline hydrolysis after $24 \mathrm{hrs}$ (Figure. 4f). The \% recovery data obtained in stress studies is presented in Table 5.

\section{CONCLUSION}

A simple and sensitive method was developed for the determination of satranidazole in its tablet dosage form. It can measure as low as $2.0 \mu \mathrm{g} / \mathrm{ml}$ with good accuracy. The proposed method could be used for routine quality control. Linear regression of absorbance on concentration gave the equation $\mathrm{y}=0.035 \mathrm{x}+0.0644$ with a correlation coefficient (r) of $0.9995 . \%$ relative standard deviation for intraday and interday precision, accuracy, ruggedness and robustness was found to be less than $2 \%$. The higher percentage recovery value indicates that there is no interference of the excipients present in the formulation. The stability studies indicates that appreciable changes were observed by treating the drug with alkaline hydrolysis, however there was no appreciable change with acidic hydrolysis, UV light, thermal stress, oxidation.

\section{ACKNOWLEDGEMENTS}

The authors are very much thankful to College of Pharmaceutical Sciences, RKGIT, Ghaziabad-201003, UP for providing all the laboratory facilities to carry out the research work.

\section{REFERENCES}

1. Zahoor A, Knight R C, Whitty P, Edwards DL, Satranidazole: mechanism of action on DNA and structure -activity correlations, Journal of Antimicrobial Chemotherapy, 18, 1986, 17-25. http:// dx.doi.org/ 10.1093/jac/18.1.17

2. Bhatia SC, Shanbhag VD, Electron-capture gas chromatographic assays of 5-nitro- imidazole class of antimicrobials in blood, Journal of Chromatography B: Biomedical Sciences and Applications, 305, 1984, 325-334. http://dx.doi.org/10.1016/S0378-4347(00)83346-0

3. Mruthyunjayaswamy BHM, Patil SMM, Raju SA, Spectrophotometric methods for the estimation of Satranidazole in pharmaceutical formulations, Indian J Pharm Sci. 63, 2001, 433-436.

4. Raju SA, Shobha M, Manjunath S, Spectrophotometric determination of satranidazole in bulk drug and formulations, Asian J Chem., 14 (1), 2002, 520- 522 .

5. Wankhede SB, Prakash A, Chitlange SS, Simultaneous spectrophotometric estimation of satranidazole in tablet dosage form, Research J. Pharm. and Tech. 1(4), 2008, 441-443.

6. Wankhede SB, Prakash A, Chitlange SS, Simultaneous spectrophotometric estimation of ofloxacin and satranidazole in tablet dosage form, Asian J. Research Chem.1 (1), 2008, 9-11.

7. Lalla J, Hamrapurkar P, Anu R, Wadhwa T, High-performance thinlayer chromatographic determination of satranidazole in its dosage form, Journal of Planar Chromatography -Modern TLC, 16(6), 2003,447-450.

8. Patel MB, Patel KM, Patel GS, Suhagia BN, Prajapati AM, Development and validation of a stability-indicating HPTLCdensitometric method for Satranidazole, Journal of Liquid Chromatography \& Related Technologies, 30(16), 2007, 2459 - 2471. http://dx.doi.org/10.1080/10826070701465852

9. Natarajan S and Raman B., HPLC determination of satranidazole in bulk and pharmaceutical dosage forms, Asian J Chem. 2008; 20(3): 18331840.

10. Prashant B, Sanjay A, Mrinalini D, Rahul G, A Validated RP-HPLC method for simultaneous estimation of ofloxacin and satranidazole from tablets, Journal of Pharmaceutical Research, 7(2), 2008,70-72.

11. Shinde RS, Suvarna IB, Namdev SP, Suman BY, Ashok MB, Simultaneous estimation of satranidazole and ofloxacin in tablet dosage form by high performance liquid chromatography, E-Journal of Chemistry, 7(1), 2010, 198-202. http://dx.doi.org/10.1155/2010/528963

12. Boopathy D, Prakash M, Mathew B, Kumar SS, Perumal P, Method development and validation of simultaneous determination of Ofloxacin and Satranidazole in pharmaceutical dosage form by RP-HPLC, Der Pharmacia Letter, 2(2), 2010, 22-26.

13. Stenlake JB, Beckett AH., The Basis of Spectrophotometry, Practical pharmaceutical Chemistry, $4^{\text {th }}$ edition, Part 2, New Delhi, CBS Publishers and Distributors; 2007, 255-7.

14. General Chapter 1225, Validation of compendial methods, USP 30 , National Formulary 25, Rockville, Md., USA, The United States Pharmacopeial Convention, Inc., (2007).

15. FDA. Guidance for Industry: Stability Testing of Drug Substances and Drug Products (draft guidance), 1998.

16. ICH Harmonised Tripartite Guideline- Validation of Analytical Procedures: Text and Methodology Q2 (R1) Nov 2005.

\section{Cite this article as:}

Vishwanath Agrahari, Meenakshi Bajpai, Sanju Nanda. Development of a simple UV-Spectrophotometric assay method for Satranidazole and study of its degradation profile. Int. Res. J. Pharm. 2013; 4(4):209-213 